\title{
Corporate Social Responsibility: Practices, Benefits and Challenges of the Master of Business Administration Students
}

\author{
Mauro Allan P. Amparado * \\ Lilet A. Pinote ** \\ Jasmin F. Hinoguin *** \\ University of Cebu Lapu-Lapu and Mandaue, \\ Mandaue City, Cebu, Philippines
}

* Director, Community Awareness, Relations \& Extension Office; mapamparado@gmail.com

** Staff, Students' Accounting Section

*** Staff, Shipboard Training Office

\section{Abstract}

This descriptive, qualitative study explored the practices of the Master of Business Administration (MBA) students in Corporate Social Responsibility (CSR). It also ascertained the benefits and challenges they encountered when conducting CSR activities in their respective organizations. The study was conducted in a university in Mandaue City, Cebu, Philippines. There were 15 students who were enrolled in the Master of Business Administration Program who served as informants. Data collection was conducted from June 2018 to October 2018. Structured one-on-one interviews were used to gather data. Each student was interviewed for one hour twice a month. Common themes were formed from the interviews.

Findings of the study revealed that there were five corporate social responsibility activities that were usually conducted by their respective organizations which includes: visiting the home for the aged and orphanage; solid waste management; coastal clean-up; tree planting; and feeding program. 
Informants narrated that the benefits of conducting corporate social responsibility activities were: better image of the company; protection of environment; and sharing of knowledge and skills to beneficiaries.

The challenges they encountered includes: monetary/budget issues; less participation from colleagues; and conflict with other organizational responsibilities.

Corporate social responsibility strengthens the trust and relationship of employees to their beneficiaries. As resources are provided to clients and communities, employees are able to appreciate the value of extending services to society and how these activities affect the lives of the people they are helping. It is also essential to determine benefits and challenges in the conduct of activities to motivate employees' participation. This study strengthens the proposition that organizations can bring social goals into the core of their business model.

Keywords: Corporate Social Responsibility, Practices, Benefits, Challenges, MBA students, Philippines.

\section{Introduction}

In recent years, many businesses have demonstrated social responsibility in the community. This trend has gained momentum over the last decade. Corporate Social Responsibility (CSR) is defined as "the continuing commitment by business to behave ethically and contribute to economic development while improving the quality of life of the workforce and their families as well as of the local community and society at large" (Wolf, Issa \& Thiel, 2015).

Enterprises should not only be profitable tools, but also be responsible citizenships. Corporate practices need a world structure to exceed imposed standards, go beyond present governments, and set goals for sustainable development. 
Multinational enterprises are responsive to the stakeholders' needs. Therefore, enterprises must focus on productive stakes in the global economy, and include social responsibility "which creates long-term sustainability for corporate success by meeting the needs of all suppliers, investors and employees" into their ownership advantage (Tai \& Chuang, 2014).

Social Responsibility adds an ethical imperative to do those things that make society better and not to do those that could make it worse. A socially responsible organization goes beyond what it must do by law or chooses to do only because it makes economic sense to doing what it can to help improve society because that's the right, or ethical, thing to do. Social responsibility requires business to determine what is right or wrong and to make ethical decisions and engage in ethical business activities. A socially responsible organization does what is right because it has an obligation to act that way. On the other hand, social responsiveness refers to the capacity of a firm to adapt to changing societal conditions. The idea of social responsiveness stresses that managers make practical decisions about the societal actions in which they engage. A socially responsive organization acts the way it does because of its desire to satisfy some expressed social need. Social responsiveness is guided by social norms. The value of social norms is that they can provide managers with a meaningful guide for decision making (Robbins \& Coulter, 2001).

Every action that organizations take involves costs as well as benefits. In recent years there has been a strong social desire to improve the cost-benefit relationship to make it possible for society to gain benefits from organizations and for the benefits to be fairly distributed. Social responsibility is the recognition that organizations have significant influence on the social system and that this influence must be properly considered and balanced in all organizational actions. The presence of strong social values such as social responsibility has a powerful impact on organizations and their actions. It leads them to use a 
socioeconomic model of decision making, in which both social costs and benefits are considered along with the traditional economic and technical values. Organizations take a broader view of their role within a social system and accept their interdependence with it (Newstrom, 2007).

No one is claiming that every business should adopt the principles of social entrepreneurs and devote all their activities to service of social goals. There are clearly other needs that businesses are designed to address. At best, social entrepreneurs demonstrate that profit is not incompatible with doing good, and therefore that one can do good profitably. On the other hand, there are some who would argue that the ethical responsibilities associated with sustainability are relevant to every business concern. In some ways, sustainability offers a model of CSR that suggests that ethical goals should be at the heart of every corporate mission (Hartman \& DesJardins, 2011).

At times, Corporate Social Responsibility and ethical management coincide with the law and local regulation. Hence, the legal prohibitions against fraud, tax evasion, pollution, bribery, child labor, sexual harassment, and job discrimination are also CSR and moral concerns. But the observance of what is legal, is only the minimum requirement of ethics and CSR. It means that something more is required of business. Learning from the sad experiences of humanity, such as the oil spill of Exxon Valdez in Alaska, USA, Marcopper disaster in Marinduque, Philippines, and the pesticide accident in Bhopal, India, business cannot but convince itself that something more is expected than obeying the law. Ethical standard has to be higher than legal compliance (Maximiano, 2014).

This study is anchored on the theory of Evan \& Freeman. Instead of focusing on generic responsiveness, specific issues or on the public responsibility principle, the approach called "stakeholder management" is oriented towards people who affect or are affected by corporate policies and practices. 
Evan and Freeman were responsible for the development of a theory of the firm based on the model of the stakeholders able to offer an account the nature and purpose of the enterprise and the moral claims that this must satisfy (Wolf, Issa \& Thiel, 2015).

It advances the proposition that the managers have a "trustrelationship" to a wide range of stakeholders of the company, meaning that suppliers, customers, employees, shareholders and the local community, as well as the management in its role as agent of these groups; those individuals or groups have a legitimate interest or a legitimate claim on the company, since they have invested time and resources in relation to it.

There is a growing recognition that some for-profit organizations also have social goals as a central part of the strategic mission of the organization. In two areas in particular, social entrepreneurship and sustainability, we find for-profit firms that do not assume a tension between profit and social responsibility. Because these firms bring social goals into the core of their business model, and fully integrate economic and social goals, this is called the integrative model of CSR. At first glance, firms that adopt the integrative model raise no particular ethical issues. Even advocates of the narrow economic model of CSR such as Milton Freidman, would agree that owners of a firm are free to make the pursuit of social goals a part of their business model (Hartman, L. P. \& DesJardins, J., 2011).

According to Rami (2016), the selection of the indicators for judging the performance of enterprise in fulfilling its social responsibilities, may be based on the following criteria: comparability; relevance and materiality; understandability; and reliability and verifiability. The guiding principles for selection of indicators may be: universality to maximize comparability; incremental approach; capability of consistent measurement; performance orientation rotes than process orientation; and 
national reporting and positive corporate contributions to development. The constraints are costs and benefits, confidentiality and trendiness.

Various studies have been conducted on corporate social responsibility. In one study, it builds on the growing body of marketing literature through two investigations that manipulate consumers' perceptions of fit, motivation, and timing of corporate social initiatives embedded within promotions. The study reveals that low-fit initiatives negatively impact consumer beliefs, attitudes, and intentions no matter what the firm's motivation, and that high-fit initiatives that are profit-motivated have the same impact. Furthermore, consumers consider the timing (proactive versus reactive) of the social initiative as an informational cue, and only the high-fit, proactive initiatives led to an improvement in consumer beliefs, attitudes, and intentions (Becker-Olsen, Cudmore \& Hill, 2006).

In another experiment, it examined the influence of corporate social responsibility and price on consumer responses. Scenarios were created to manipulate corporate social responsibility and price across two domains (environment and philanthropy). Results from a national sample of adults indicate that corporate social responsibility in both domains had a positive impact on evaluation of the company and purchase intent. Furthermore, in the environmental domain corporate social responsibility affected purchase intent more strongly than price did (Mohr \& Webb, 2005).

While it is generally agreed that companies need to manage their relationships with their stakeholders, the way in which they choose to do so varies considerably. In the study of Morsing \& Schultz (2006), they argued that when companies want to communicate with stakeholders about their CSR initiatives, they need to involve those stakeholders in a two-way communication process, defined as an ongoing iterative sense-giving and sense-making process. The paper also argues that companies 
need to communicate through carefully crafted and increasingly sophisticated processes. Three CSR communication strategies are developed. Based on empirical illustrations and prior research, the authors argue that managers need to move from 'informing' and 'responding' to 'involving' stakeholders in CSR communication itself. They conclude that managers need to expand the role of stakeholders in corporate CSR communication processes if they want to improve their efforts to build legitimacy, a positive reputation and lasting stakeholder relationships.

University of Cebu Lapu-Lapu and Mandaue (UCLM) envisions itself to democratize quality education, be the visionary and industry leaders, and give hope and transform lives. It commits to Pursue excellence in instruction, research, and community service towards social and economic development as well as environmental sustainability (Amparado, 2013). Spearheaded by the UCLM Community Awareness, Relations and Extension Services Office, the university has funded researches which led to the creation and implementation of extension services for the campus and partner communities in Cebu City, Mandaue City, and Lapu-Lapu City.

These researches include: needs assessment of communities (Amparado, Camayra, Dorio Jr. \& Patindol, 2017; Amparado \& Colonia, 2020; Montecillo \& Amparado, 2015); studies on community literacy and education (Ruiz, Pilapil, Rule, Tulod \& Amparado, 2019; Sumalinog \& Amparado, 2020; Semblante \& Amparado, 2019; Amparado \& Pioquinto, 2020; Amparado \& Ocariza, 2018; Amparado \& Ocariza, 2020); solid waste management (Amparado \& Diamante, 2016; Amparado \& Saladaga, 2020); greening management (Amparado, Sumalinog \& Moralde, 2020); nutrition studies (Dorio Jr. \& Amparado, 2020); coastal management studies (Amparado, Lumanta \& Tisoy, 2020); entrepreneurship (Baladjay, Amparado, Manatad \& Rosal, 2019); green products (Tejedor, Nugal \& Amparado, 2018); HIV/AIDS awareness (Famador \& Amparado, 2018; 
Amparado, 2019); and anti-violence against women and their children (Caparas \& Amparado, 2012).

The above-mentioned studies have utilized community residents, faculty and college students as respondents. However, the university have very few studies that investigated on the views of students pursuing graduate studies. Hence, this study explored the practices of the Master of Business Administration (MBA) students in Corporate Social Responsibility (CSR). It also ascertained the benefits and challenges they encountered when conducting CSR activities in their respective organizations.

\section{Methods}

This qualitative research utilized the descriptive exploratory design. The study was conducted at UCLM, Mandaue City, Cebu, Philippines. There were 15 students who were enrolled in the Master of Business Administration Program and served as informants. Data collection was conducted from June 2018 to October 2018. Structured one-on-one interviews were used to gather data. Each student was interviewed for one hour twice a month. Common themes were formed from the interviews.

\section{Results and Discussion}

\section{A. Corporate Social Responsibility (CSR) Activities}

When we interviewed the fifteen MBA students who shared their CSR activities, data saturation was evident among five activities.

\section{Visiting the home for the aged and orphanage}

One of these activities is visiting the home for the aged and orphanage. The home for the aged and orphanage provides a second home for all abandoned, sick and homeless elderly and 
children in Cebu. As shared by one informant, "We provide them their basic needs like food items, used clothing, blankets, toys, and medicines. It is so heart-warming to see them smile when we provide them the items."

One informant shared, "I wonder where their relatives or families are. I could not imagine myself leaving my grandparents in this place. I also have the same feeling when I visit a home for the orphanage. Some kids are so young, I would embrace them and be glad to see their faces light up when we give them toys."

\section{Solid Waste Management}

Cleaning the streets from solid wastes was another common answer. As narrated by one informant, "We joined a one-of-a-kind fun run where participants collect trash on the streets while running along a five-kilometer route. This activity has been held in Cebu City, San Carlos City, Butuan City, Municipality of Minglanilla and Municipality of Cordova. The runners would bring with them black bags and pick up solid wastes on the streets."

It was also noted by the researchers that the informants were implementing solid waste management in their respective organizations. Initiatives such as the creation of Materials Recovery Facility, segregation of wastes, and banning the use of plastics in their canteens were evident.

\section{Coastal Clean-up}

A significant number of informants shared that their organizations have participated in quarterly coastal clean-ups. This was strengthened by the national initiative of the Department of Environment and Natural Resources since implementing the National Orchestrated Coastal Clean-up. 
One informant shared, "Whenever we do coastal clean-ups, we are able to gather sacks of non-recyclables. And every time we visit the area, we experience the same conditions. Aside from helping the communities through clean-ups, I think educating them about the importance of caring for the environment is essential."

\section{Tree planting}

Another corporate social responsibility activity mentioned by the informants is tree planting. They would go to mountain communities and plant fruit-bearing trees and other trees provided by the local government unit. One informant said, "I love going up the mountains and feeling the fresh air. I always feel excited and a rush of freedom is felt when I am on a higher ground. We also feel very happy when we revisit the trees we have planted which have grown tall."

\section{Feeding program}

Feeding programs were also a common response from the informants. Most would visit schools to provide free breakfast or lunch to children. One informant shared, "We offer the students hot rice porridge. Sometimes we distribute bread and milk. For lunch, we give them rice and fish. Most of the students would tell us that their parents do not have money to provide them breakfast."

\section{B. Benefits of Corporate Social Responsibility}

\section{Better image of the company}

According to Robbins \& Coulter (2011), firms seek to enhance their public image to get increased sales, better employees, access to financing, and other benefits. Because the public considers social goals important, business can create a favorable public image by pursuing social goals. 
One informant said, "When people have noticed that we were doing corporate social responsibility activities, they have admired our organization more. It has increased the trust and confidence from our clients. Our sales have increased too."

\section{Protection of the Environment}

Most of the informants believe that whenever they do tree planting, coastal clean-ups and solid waste management, the environment is always protected. The informants see the advantages of corporate social responsibility to the environment. They see a cleaner, vibrant and greener environment.

\section{Sharing of resources to beneficiaries}

One informant said, "It is a privilege to be able to share our resources to community residents. Majority of our beneficiaries have not finished elementary education. And every time we teach them and share to them what we have, they are very appreciative of it. It reflects on their faces and their words. And it brings back joy to us."

\section{Challenges}

\section{Monetary/budget issues}

One of the issues encountered by the MBA students when conducting CSR activities is the monetary aspect. Although some students claimed that CSR activities are discussed during organizational meetings, in most cases, these activities are not part of the annual budget. They would request the budget from the owners of the organization. One informant said, "We have difficulty implementing activities because the release of budget may either be delayed, or they would decrease the amount of our budget. 


\section{Less participation from colleagues}

Most of the informants said that they have colleagues who have less participation or no participation in corporate social responsibility activities. "Some of our colleagues do not join the activities because they do not have much time to be involved. Sometimes, I do not join scheduled activities too. I have two kids and a wife who needs my help at home. During my day off, I dedicate my time to household chores. We do not have helpers at home. I pity my wife when I see her doing the laundry the entire day. And so, I help her. It is also the time when I can play with my two boys."

\section{Conflict with other organizational responsibilities}

Another challenge faced by the MBA students are organizational responsibilities which hinder them from joining the activities. This includes meetings, sales calls, deadlines, and documents to be submitted and filed.

One informant shared, "We also have events in our organization which are usually scheduled on weekends. Most of the time, preparations for these events are given more importance than conducting extension services to the community."

\section{Conclusion}

Corporate social responsibility strengthens the trust and relationship of employees to their beneficiaries. As resources are provided to clients and communities, employees are able to appreciate the value of extending services to society and how these activities affect the lives of the people they are helping. It is also essential to determine benefits and challenges in the conduct of activities to motivate employees' participation. This study strengthens the proposition that organizations can bring social goals into the core of their business model. 


\section{Literature Cited}

Amparado, M. A. P. (2013). University of Cebu Research Center Manual. Philippines: University of Cebu.

Amparado, M. A. P. (2019). Awareness, Acceptance and Attitude on HIV/AIDS: Perspectives of Students in a University. Cebu Journal of Nursing, 2(1), 29-40.

Amparado, M. A. P., Camayra, M. T., Dorio, Jr. P. A. \& Patindol, D. B. (2017). Sustainable Community Extension Programs for Village Looc, Mandaue City, Cebu, Philippines: The $8^{\text {th }}$ Year Re-assessment. IAMURE International Journal of Social Sciences, 19(1), 102-114.

Amparado, M. A. P. \& Colonia, G. E. (2020). Community Needs Assessment of Village Opao, Mandaue City, Cebu, Philippines. Cebu Journal of Teacher Education 1(1), 83100.

Amparado, M. A. P. \& Diamante, V. A. M. (2016). Paying School Fees through Wastes: The Experiences of an Eco Scholar. International Journal of Social Sciences \& Educational Studies, 3(2), 54-60.

Amparado, M. A. P., Lumanta, N. L. \& Tisoy, R. I. (2020). Impact of the Coastal Management Program to Community Residents. Cebu Journal of Maritime Education, 1(1), 88100.

Amparado, M. A. P., Moralde, K. Y. \& Sumalinog, J. A. (2020).

Needs Assessment of the University's Greening

Management Program. Cebu Journal of Teacher Education, 1(2), 91-100.

Amparado, M. A. P. \& Ocariza, R. D. P. (2018). Assessing the 
Health Education and Literacy Needs of Partner

Communities. Cebu Journal of Nursing, 1(1), 25-40.

Amparado, M. A. P. \& Ocariza, R. D. P. (2020). Evaluation of the Health Education and Literacy Program (HELP) to

Community Residents. Cebu Journal of Nursing, 3(1), 93100.

Amparado, M. A. P. \& Pioquinto, P. V. (2020). Karate Program as an Extension Service: Impact and Challenges. Cebu Journal of Criminal Justice, 1(2), 87-100.

Amparado, M. A. P. \& Saladaga, M. K. A. (2020). Money from Wastes (Pera sa Basura) Program of a University in Central Visayas, Philippines: An Impact Study. Cebu Journal of Business and Accountancy, 2(1), 74-87.

Baladjay, R. A., Amparado, M. A. P., Manatad, J. \& Rosal, M. (2019). Educating the Out-of-school Youth on Entrepreneurship: Community Extension Program Impact Study. Cebu Journal of Business \& Accountancy, 1(1), 89-100.

Becker-Olsen, K. L., Cudmore, B. A., \& Hill, R. P. (2006). The impact of perceived corporate social responsibility on consumer behavior. Journal of business research, 59 (1), 46-53.

Caparas, M. A. E. \& Amparado, M. A. P. (2012). Women's Awareness on the Law on Anti-Violence Against Women and their Children. JPAIR Multidisciplinary Research, 8(1), 66-80.

Dorio Jr., P. A. \& Amparado, M. A. P. (2020). Establishing a Breakfast Club in the University. Cebu Journal of Hospitality and Tourism Management, 1(1), 90-100. 
Famador, M. C. \& Amparado, M. A. P. (2018). Targeting Wellness, Examining the Scourge: Views from the Academe on HIV/AIDS. Paper presented in the 2018 University of Cebu Research Congress, 12(1), 21.

Hartman, L. P. \& DesJardins, J. (2011). Business Ethics:

Decision Making for Personal Integrity \& Social Responsibility. $2^{\text {nd }}$ edition. New York: McGraw-Hill.

Maximiano, J. M. B. (2014). Business Ethics and Corporate Social Responsibility. Revised edition. Philippines: Anvil Publishing Inc.

Mohr, L. A., \& Webb, D. J. (2005). The effects of corporate social responsibility and price on consumer responses. Journal of consumer affairs, 39 (1), 121-147.

Montecillo, C. P. V. \& Amparado, M. A. P. (2015). Community Health Needs of Barangay (Village) Hipodromo, Cebu City, Cebu, Philippines. Journal of Research in Nursing, $1(1), 20-29$.

Morsing, M., \& Schultz, M. (2006). Corporate social responsibility communication: stakeholder information, response and involvement strategies. Business ethics: a European review, 15(4), 323-338.

Newstrom, J. W. (2007). Organizational Behavior: Human Behavior at Work. $12^{\text {th }}$ edition. Singapore: Mc-Graw Hill.

Rami, G. (2016). Corporate Social Responsibility:

A Methodology for Performance Evaluation. Global Journal of Research in Management, 6(1), 1.

Robbins, S. P. \& Coulter, M. (2011). Management. $6^{\text {th }}$ edition. Singapore: Pearson Education Asia Pte. Ltd. 
Ruiz, G. C., Pilapil, G. F. L., Rule, K. J. A. L., Tulod, S. A. L. \& Amparado, M. A. P. (2019). Evaluation of the Playgroup Project and Alternative Learning System Programs in Village Looc and Village Opao, Mandaue City, Cebu, Philippines. JPAIR Institutional Research, 12(1), 23-39.

Semblante, J. N. \& Amparado, M. A. P. (2019). Needs Assessment of the Participants of Computer Literacy Program (CLIP) in Partner Community. Cebu Journal of Computer Studies, 2(1), 73-78.

Sumalinog, J. A. \& Amparado, M. A. P. (2020). Small Group Teaching Program of the Junior High School Department: Impact and Challenges. Cebu Journal of Teacher Education, 1(1).

Tai, F. M., \& Chuang, S. H. (2014). Corporate social responsibility. Ibusiness, 6 (03), 117.

Tejedor, A. Z., Nugal, C. A. \& Amparado, M. A. P. (2018). Green Products from the Lens of Graduate School Students. International Journal of Social Sciences and Educational Studies, 5(1), 1-6.

Wolf, R., Issa, T. \& Thiel M. (2015). Empowering Organizations through Corporate Social Responsibility. Hershey, PA: IGI Global. 